\title{
Trubarjev Philopatridus Illyricus
}

\author{
France Novak (Ljubljana)
}

IZVLEČEK: V sestavku avtor kritično obravnava slovenski prevod Trubarjevega psevdonima Philopatridus Illyricus z izrazoma rodoljub ilirski in se odpoveduje svoji nekdanji domnevi, da se nanaša na Matijo Vlačića Ilirika.

ABSTRACT: The author critically examines the Slovenian translation of Primož Trubar's pseudonym Philopatridus Illyricus - that is, rodoljub ilirski 'the Illyrian patriot' - and rejects his earlier hypothesis that this was actually the pseudonym of Matija Vlačić Ilirik.

1 Trubarjev Philopatridus Illyricus ne bi smel biti problem, saj je splošno znano, da je Trubarjev psevdonim v prvi slovenski knjigi. Meni je kljub temu postal problematičen zaradi slovenske ustreznice rodoljub ilirski (Rupel 1966, 16). V tej obliki lahko namreč vzbuja napačne predstave, saj je beseda ilirski dobila v slovenščini po Trubarjevem času več novih pomenskih odtenkov, sam Trubar pa tudi drugi slovenski pisci tega časa je v slovenščini niso uporabljali. ${ }^{1}$ To je bilo vzrok za prvi pomislek. Drugi pomislek sem imel zaradi tega, ker je bil Philopatridus Illyricus uporabljen v bližini pridige o veri, ki jo je napisal Matija Vlačić Ilirik - Matthias Flacius Illyricus. Zato sem sklepal, da je morda s tem vzdevkom mišljen avtor pridige o veri - Matthias Flacius Illyricus. Pridevnik illyricus sem spravil v zvezo z njim. To misel sem tudi dvakrat zapisal, in sicer v Novak 2001, 116-117 in Novak 2004, 36, v opombi. Po natančnejšem pregledu gradiva spreminjam trditev: Philopatridus Illyricus je psevdonim za Primoža Trubarja. Pojdimo po vrsti.

1.1 P. Trubar uporablja to ime na naslovnici TC 1550. Navajam kontekst:

\section{Catechifmus}

In der Windifchenn Sprach/

fambt einer kürtzen Außlegung

in gefang weiß. Item die Lita $=$

1 Trditev je postavljena na podlagi podatkov kartoteke popolnega izpisa slovenskega besedja slovenskih protestantskih piscev 16. stoletja v Sekciji za zgodovino slovenskega jezika Inštituta za slovenski jezik F. Ramovša ZRC SAZU. 


\author{
nai vnd ein predig vom rech \\ ten Glauben/ geftelt/ durch \\ Philopatridum \\ Illiricum.
}
Anu kratku Poduuzhene lkate= rim vfaki Zhlouik more $\mathrm{v}=$ nebu pryti.

Problem je bil v tem, na kaj se nanaša geftelt/ durch Philopatridum Illiricum (sestavil Philopatridus Illiricus). Če bi veljal za celoten naslov, bi šlo za Trubarjev psevdonim, če bi veljal samo za zadnji podatek ein predig vom rechten Glauben/ geftelt/ durch Philopatridum Illiricum, bi se nanašal na Matija Vlačića Ilirika. Ker gre za drugo poved v naslovu, se mi je zdel pomislek kar verjeten.

2 Glavni podatek o stvari pove že sam Trubar v publikaciji Regifter vnd fummarifcher Innhalt ... Tübingen, 1561. Na strani B III a o TC 1550 pravi: Diß Büchlin ift deß Trubers erfte Prob/ ob man auch die Windifchen Sprach/ fchreiben vnd lefen möchte/ wölches er heimlich vnnd vnder einem erdichten Namen/ (von wegen/daß jme die Superattendenten der Truckereyen/an zweyen orten/zur zeitt deß Interims/gemelt Büchlin/zutrucken nicht wolten geftatten) hat müffen trucken lasfen/ daffelbig helt inn fich dife nachuolgende Stuck. ${ }^{2}$

Drugo mesto v tej publikaciji, ki pojasnjuje to vprašanje, je 19. točka: Am letften/ift ein gantze Predig/von dem Wort/Glaube/vnd von Glaubens eigenfchafft vnd würckungen/ colligiert auß Illirici Büchlin/de voce \& re fidei (TR 1561, B IIII a). ${ }^{3}$

Trubar sam pove, da je publikacijo izdal pod izmišljenim imenom. Psevdonima ne povezuje s piscem pridige Ilirikom.

2.1 Matija Vlačić Ilirik je bil znan pod imenom Illyricus, kot smo videli že iz Trubarjevega navedka (TR 1561, B IIII a), enako je v Kreljevem naštevanju reformacijskih teologov Illyrikuf(KB 1566, E 6) ali pa s celotnim imenom, npr. Illyricus, Mathias Flacius s. [glej] Flacius Illyricus, Mathias (VD 16, Band 9, str. 626).

Da bi za Vlačića veljal Philopatridus Illyricus, nisem dobil nikjer izpričano.

2 V prevodu se glasi: Ta knjižica je Trubarjev prvi poskus, ali bi se tudi slovenski jezik dal pisati in brati; moral jo je dati tiskati na skrivaj in pod izmišljenim imenom (ker mu nadzorniki tiskarn v dveh krajih za časa interima natisa omenjene knjižice niso hoteli dovoliti). Le-ta vsebuje tele razdelke. Rajhman 1986: 43.

$3 \mathrm{~V}$ prevodu: Na koncu je celotna pridiga o besedi vera in o lastnostih in učinkih vere, povzeta iz Ilirikove knjižice de voce \& re fidei (Rajhman 1986: 49). 
Nima ga Mijo Mirković v monografiji Matija Vlačić Ilirik, Zagreb 1960. Tudi VD 16 pozna to ime samo za Trubarjev psevdonim (VD 16, Band 16, str. 58).

3 Poglejmo še vzorec naslovov knjig slovenskih protestantskih piscev, da bomo videli, kakšno vlogo imajo imena na takih mestih. V vzorec naslova štejemo, kar je na prvem mestu na naslovnici in kar je pred naslovom $v$ drugem jeziku, če je naslov v dveh jezikih, ali pred kakim citatom. Glavni vzorec ima praviloma dolg naslov in ime prireditelja, omenjenega na koncu ali proti koncu naslovnega teksta. Torej velja za vso knjigo. Tudi, če obsega več kot eno poved, kar je uporabljeno v TC 1550. Model dela povedi, ki kaže na sestavljalca ali prevajalca knjige, je praviloma tak kot v nemških naslovih: trpni deležnik + prislovno določilo vršilca dejanja; v nemščini geftelt/ durch Philopatridum Illiricum, v slovenščini pa te fo prepifane od aniga Peryatila vfeh Slouenzou. Trpni deležniki, ki se uporabljajo, so še: zveistu preobernen, zveistu tolmačen, zastopnu izložen, iztolmačen, zložen, vkupe zbran, stolmačen ipd. (Berčič 1968, 168-250).

3.1 Prireditelj je imenovan na naslovnicah naslednjih izdaj: TC 1550 (durch Philopatridum Illiricum), TA 1550 (od aniga Peryatila vfeh Slouenzou), ${ }^{4}$ TT 15571558 (Skufi Primosha Truberia), TT 1560 (skufi Primosha Truberia Crainza), TL 1561 (SKVSI PRIMOSHA Truberia Crainza), TAr 1562 (skufi Primosha Truberia Crainza), TPs 1566, TC 1567 nekoliko prilagojen vzorec), TL 1567, TP 1567, TPs 1567 (od P. Truberia, s. Krelia, inu od drugih sloshene), TC 1574, TP 1575 (nekoliko prilagojen vzorec), TC 1575 (skufi Primosha Truberia), DPa 1576 (šele v drugi, nemški varianti naslova je Durch. M. Georgium Dalmatinum), TT 1577 (od Primosha Truberia), DB 1578 (skusi Iuria Dalmatina), TM 1579 (Skusi Iansha Tulszhaka), TC 1579, DPr 1580, TT 1581-82 (skufi Primolha Truberia Crainza Raftzhizheria), DB 1584 (Ckusi IVRIA DALMATINA), DC 1584, DM 1584, BH 1584 (ADAMI BOHORIZH), TPo 1595, DM 1595, TfC 1595, ZK 1595 (SKVSI Iansha Snoillhika). Ta vzorec je močno prevladujoč. Uporabljala sta ga zlasti Trubar in Dalmatin. (Prim. Berčič 1968, 168-250).

Tudi vzorec naslova kaže, da je Philopatridus Illyricus v TC 1550 Trubarjev psevdonim.

3.2 Podatki o avtorjih prevedenih ali prirejenih del se navajajo sprva redkeje, proti koncu obdobja pa čedalje pogosteje, vendar so njihove omembe pred imenom prireditelja, bodi da so sestavni del prvega glavnega dela naslova, npr. HISHNA POSTILLA D. MARTINA LVTHERIA (TPo 1595) ali pa KATECHISMVS DOCTORIA MARtina Luthra (ZK 1595). Tudi ta podatek bi kazal na to, da mesto Philopatrida Illyrica ne kaže na avtorja enega izmed besedil, vključenih v TC 1550.

4 Prvi dve knjigi imata najprej naslov v nemščini, šele na drugem mestu je slovenski. Pri drugih knjigah v slovenščini je na začetku slovenski naslov. 
4 Oglejmo si naslovnico druge Trubarjeve knjižice, ki je izšla hkrati s Catechismom, to je TA 1550. Tudi ta ima najprej naslov v nemščini:

\section{Abecedarium \\ vnd der klein Catechifmus \\ In der Windifchen \\ Sprach.}

Ane Buquice/ is tih fe ty

Mladi inu preprofti Slouenci

mogo lahku vkratkim zhafu

brati nauuzhiti/ Vtih fo tudi

ty vegfhy ftuki te kerfzhanfke

Vere inu ane Molytue/

te fo prepifane od ani=

ga Peryatila vfeh

Slouenzou.

Zanimivo je, da imamo v drugi Trubarjevi knjigi (TA 1550) slovensko varianto nemško-latinskega psevdonima iz TC 1550 - od aniga Peryatila vfeh Slouenzou. Namesto pridevnika illyrikus imamo tu ime Slovenci. Spet moramo opozoriti na to, da v takratni slovenščini ni pridevnika ilirski. Do neke mere bi ga lahko nadomeščal pridevnik slovenski, katerega glavni pomen bi bil »slovanski s tistega dela ozemlja, kjer je bila rimska provinca Ilirik«.

4.1 Ker je Philopatridus Illyricus psevdonim iz naslova v nemščini, je namenjen nemškemu jezikovnemu okolju in ker je v latinščini, je značilen tudi za latinščino tistega časa. Ni najboljša rešitev, če ga v slovenščino prevajamo dobesedno rodoljub ilirski. Avtorjev ustreznik je Peryatil veh Slouenzou. Sklepam, da je perjatil vseh Slovencov po vsebini pravi ustreznik za nemško-latinski Philopatridus Illyricus.

4.2 O pravilnosti takega sklepanja imamo še en dokaz. Krajevno ime Ilirik se uporablja v Bibliji, in sicer v Pavlovem pismu Rimljanom (Rim 15, 19). To mesto se v Vulgati glasi: ita ut ab Ierusalem per circuitum usque ad Illyricum repleverim evangelium Christi (Vulgata 1946, 1068), pri Lutru pa: Also/ das ich von Jerusalem an vnd vmbher bis an Jllyricum/ alles mit dem Euangelio Christi erfüllet habe (Luther 1545, 2293). Ime pozna tudi slovenski prevod Svetega pisma: Vse od Jeruzalema tja do Ilirika sem v velikem krogu dopolnil Kristusov evangelij (SP 1996, 1702). Če upoštevamo te podatke in primerjamo med seboj psevdonima iz TC 1550 in iz TA 1550, lahko sklepamo, da gre tudi pri pridevniku illyricus za nemško-latinsko varianto psevdonima, pri imenu Slovenci pa za slovensko, saj tako Trubar kot tudi Dalmatin prevajata ta del Pavlovega pisma Rimljanom z izrazom Slovenske dežele: Taku, de fem od Ierufaleme inu undukai okuli noter do te Slouenske deshele napolnil fteim Euangeliom Criftufeuim (TT 1560, 24 b-25 a); ... Taku, de fim jeft 
od Ierusalema, inu okuli notèr do Slovenfke deshele, vfe s'Criftufovim Evangeliom napolnil (DB 1584, III, 88 a).

Ilirik je rimska provinca na severozahodnem delu Balkanskega polotoka (Kastelic 1990: 106). Trubar in Dalmatin sta ga prevajala Slovenske dežele, kar pomeni $\mathrm{v}$ tistem času to, kar poimenujemo danes slovanske in slovanski vključuje tudi pridevnik slovenski. V Trubarjevem času ni ta provinca več obstajala. Namesto ilirski bi Trubar uporabljal slovenski. Treba je povedati tudi to, da je bilo v Trubarjevem času na tem ozemlju drugačno stanje kot za časa Rimljanov. Kasneje je izraz ilirski prišel v rabo tudi v slovenščino, in sicer v drugačnih pomenih. Če bi prevajali Philopatridus Illyricus kot rodoljub ilirski, bi se nekako približali Trubarjevemu pojmovanju, vendar ne natančno. Ta pot niti ni potrebna, ker je avtor sam dal slovenski ustreznik latinskemu psevdonimu - Peryatil veh Slouenzou. Pa tudi ta psevdonim je treba pojasniti: Slovenec je takrat pomenil tudi druge Slovane, Slovence avtomatično neposredno. Pomemben je pri tem zaimek vseh. Pri psevdonimu ni mislil samo na Slovence v današnjem smislu, če želi poudariti samo ta pomen, potem jih imenuje tudi z bolj natančnim izrazom oz. izrazi, saj velikokrat uporablja pokrajinska imena. To razlaganje bi bilo najenostavnejše.

4.3 Rodoljub ilirski torej kot prevod ni dober, ker je preveč prekrit z novejšimi pomeni, ki so prišli v slovenščino kasneje in ne odražajo natančno tiste misli, ki jo je Trubar izrazil v nemškem jeziku s pomočjo latinskih izrazov, v očitnem slovenskem ustrezniku pa kot prijatelj vseh Slovencev.

\section{Viri in literatura}

Berčič 1968 = Branko Berčič, Das slowenische Wort in den Drucken des 16. Jahrhunderts, Bibliographie, Abhandlungen über die slowenische Reformation, München 1968, 163-250.

Kastelic 1990 = Jože Kastelic, Ilirik, Enciklopedija Slovenije 4, Ljubljana 1990, $106-107$.

KB 1566 = Sebastijan Krelj, OTROZHIA BIBLIA, Regensburg 1566.

Luther 1545 (1974) = Martin Luther, Biblia, Das ist die ganze Heilige Schriff, Deudsch auffs new zugericht, Wittenberg 1545, I-III, München 1974.

Mirković 1960 = Mijo Mirković, Matija Vlačić Ilirik, Zagreb 1960.

Novak 2001 = France Novak, Kako so protestantski pisci 16. stoletja poimenovali nove pojme, Zbornik posvetovanja 450-letnica slovenske knjige in slovenski protestantizem, Ljubljana 2001, 103-120.

Novak 2004 = France Novak, Samostalniška večpomenskost v jeziku slovenskih protestantskih piscev 16. stoletja, (Zbirka Linguistica et philologica), Ljubljana, 302 str.

Rajhman 1986 = Jože Rajhman, Pisma Primoža Trubarja, Ljubljana 1986.

Rupel 1966 = Mirko Rupel, Slovenski protestantski pisci, Druga dopolnjena izdaja, Ljubljana 1966. 
$4 \quad$ Sveto pismo $1966=$ Sveto pismo stare in nove zaveze, Slovenski standardni prevod iz izvirnih jezikov, Ljubljana 1996.

TA $1550=$ Primož Trubar, Abecedarium vnd der klein Catechifmus, Tübingen 1550.

TC 1550 = Primož Trubar, Catechifmus, Tübingen 1550.

TR 1561 = Primož Trubar, Regifter vnd fummarifcher Inhalt, Tübingen 1561 .

VD 16 = Verzeichnis der im deutschen Sprachbereich erschienenen Drucke des XVI. Jahrhunderts, I. Abteilung, Verfasser-Körperschaften-Anonyma, 1-22, Stuttgart 1983-1995.

Vulgata 1946 = Bibliorum Sacrorum iuxta Vulgatam Clementinam, Nova editio, Curavit Aloisius Gramatica, 1946.

\section{Primož Trubar's Philopatridus Illyricus}

Summary

This article critically examines the Slovenian translation of Primož Trubar's pseudonym Philopatridus Illyricus used in his first book, Catechismus (Catechism, TC 1550). The pseudonym was translated as rodoljub ilirski 'the Illyrian patriot' despite the fact that the word ilirski is unknown in the Slovenian language that Trubar used. However, in his Abecedarium (Abecedary), which was published simultaneously with Cathecismus, he used the Slovenian equivalent of the Latin Philopatridus Illyricus - that is, Peryatil vfeh Slouenzou 'a friend to all Slovenians'. The author rejects his earlier hypothesis that Philopatridus Illyricus actually referred to Matija Vlačić Ilirik (a.k.a. Matthias Flacius Illyricus).

France Novak

Inštitut za slovenski jezik Frana Ramovša ZRC SAZU

Novi trg 2, 1000 Ljubljana

FNovak@zrc-sazu.si 